\title{
Korozif özofajit olgusunda oral glutamin desteği
}

\author{
Oral glutamine support in a Corrosive esophagitis patient \\ Cengizhan Emre*, Ilhami Demirkapu, Cihan Döğer, Didem Katar, Semih Aydemir, \\ Metin Kılınç
}

Anesteziyoloji ve Reanimasyon Kliniği (Dr. C. Emre, Dr. İ. Demirkapu, Dr. C. Döğer, Dr. S. Aydemir, Dr. M. Kılınç), Göğüs Hastalıkları Kliniği (Dr. D. Katar), Etlik İhtisas Eğitim ve Araştırma Hastanesi, TR-06070 Ankara

*iletişim adresi:

Dr. Cengizhan Emre, Anesteziyoloji ve Reanimasyon Kliniği, Yenimahalle Devlet Hastanesi, TR06370 Ankara. E-posta: drcemre@gmail.com

Sayın Editör,

Yakıcı maddelerin alımı sonrasında, ösofagusta gelişen inflamasyon ve hasar koroziv osofajit olarak adlandırılır. Koroziv ösofajit nedeni olan madde asit veya alkali, sıvı ya da katı olabilir. Koroziv ösofajitlerin \%75-90'ından alkali maddeler sorumludur ve önemli sekellerin gelişmesi de daha çok alkali kimyasallar nedeniyle olmaktadır. Bu yakıcı maddelerin özellikle de alkali kimyasalların alımı üst gastrointestinal sistemde, perforasyona ve ölüme neden olabilir $[1,2]$. Potasyum suda çözünen güçlü alkali bir elementtir. $\mathrm{Bu}$ makalede saf potasyum çözeltisinin içilmesine bağlı gelişen koroziv ösofajitli olgu sunulmaktadır.

Elli yedi yaşında çiftçilikle uğraşan erkek hasta tarlada çalışırken susuzluğunu gidermek amacıyla su olduğunu düşündüğü, su gibi berrak, kokusuz, sıvıdan içtiğini ancak içtikten hemen sonra ağzında yanma ve acı tat hissetmesi üzerine geri çıkardığını ifade etti. Yanma hissinin şiddetlenmesi ve solunum sıkıntısı nedeniyle hastaneye getirilen hasta hastanemiz acil servisininde monitörize edildi. Fizik muayenede oral mukoza hiperemik, uvula ödemliydi. Dinlemekle akciğerlerinde stridor ve yaygın ronküs tespit edildi. Endoskopik incelemede; oral mukoza, uvula ve epiglot çevresinde ileri derecede ödem ve eksudalar izlendi. Özefagus proksimalinden itibaren lümeni çepeçevre saran kirli sarı renkte kalın tabaka oluşturmuş eksuda izlendi, mideye zorlanarak geçildi. Mide mukozası normal izlendi. Klavuz tel eşliğinde mideye beslenme tüpü yerleştirildi. Hastanın oral alımı kesildi. Yoğun bakımda hastaya klaritromisin $500 \quad \mathrm{mg} \quad 2 \times 1 \mathrm{~g}$ IV, ampisilin/sulbaktam $4 \times 1 \mathrm{~g}$ IV, teofilin $200 \mathrm{mg}$ solüsyon $2 \times 1$, parasetamol solüsyon $3 \times 1000 \mathrm{mg}, 100 \mathrm{mg}$ ranitidin HCL ve parenteral beslenme başland1. Yedinci gün sonunda hastaya glutamin $2 \times 5 \mathrm{mg}$ /gün oral olarak başlandı. Yirmi bir günlük oral glutamin tedavisi sonrasında endoskopide mukozanın iyileştiği, ösefagusta yapısal kalınlaşmalar olduğu görüldü. Hastada yutma güçlügü oluşmadı.

Koroziv ösofajit' in ülkemizdeki sıklığı kesin olarak bilinmemektedir. Koroziv ösofajit tedavisinde amaç perforasyon, enfeksiyon, strüktür gelişiminin önlenmesi ve hasarlanmış dokunun onarımının sağlanmasıdır. Bu amaçla hastaların oral alımı kesilirken, antiasit tedavi, antibiyoterapi ve destek tedavileri uygulanır $[1,2]$. Tedavide oral sukralfat ve $\mathrm{n}$ asetilsistein etkinliğini gösteren yayınlar bulunmaktadır [3, 4]. Fakat koroziv özofajit tedavisinde oral glutamin kullanımı ile yapılmış çalışma ya da olgu bildirimi bulunmamaktadır. Glutamin esansiyel olmayan bir aminoasittir [5]. İmmünite arttırıc1 özelliği yanında, artmış katabolik durumlarda glutatyon sentezi, artmış protein sentezi ve glukoneogenez için önemli bir substrattır. İhtiyaç durumunda iskelet kaslarındaki glutamin kullanılır ancak katabolik durumlarda ihtiyacı karşılamada yetersiz kalır. Bu özellikleri nedeniyle yoğun bakım ünitelerindeki hastalarda besleme desteği olarak 
sıklıkla kullanılmaktadır. Glutamin, GİS hücreleri için primer enerji kaynağı olup mukoza iyileşmesinde, atrofinin engellenmesinde ve bakteriyel translokasyonun önlenmesinde önemli rol oynar [6,7]. Biz bu etkilerini dikkate alarak, saf potasyum çözeltisi içimine bağlı korozif ösofafitli hastamıza oral yolla $200 \mathrm{~mL}$ su içinde $5 \mathrm{mg}$ toz glutamin bulunan çözelti kullandık. Üç haftalık tedavi sonunda hasta prognozunun iyi olduğunu gözlemledik. Korozif ösofajit tedavisinde, mukoza hasarının onarımı ve hızlı iyileşmenin desteklenmesi amacıyla oral yolla kullanılan glutamin desteğinin faydalı olabileceğini düşünüyoruz. Glutaminin korozif ösofagitteki etkinliğinin belirlenmesi için kontrollü ve geniş hasta grupları ile yapılan çalışmalara ihtiyaç bulunmaktadır.

\section{Kaynaklar}

1. Karaoğlu A. Önder, Özütemiz Ö. Akut korozif özofajit; 108 olgunun değerlendirilmesi Turk J Gastroenterol 1998; 1: 55-60.

2. Ramasamy K, Gumaste VV. Corrosive ingestion in adults. J Clin Gastroenterol 2003; 37: 119-24.

3. Gümürdülü Y, Karakoc E, Kara B, Taşdoğan BE, Parsak CK, Sakman G. Koroziv özofajitte sükralfatn belirgin etkinliği: Randomize ve prospektif çalışma. Turk J Gastroenterol 2010; 21: 7-11.

4. Yetim TD, Yetim İ, Duru M. Korozif özofajit tedavisinde n-asetil sistein kullanımının erken donemde Striktur Gelişimini Engellemedeki Etkinliği JAEM 2011: 73-5.

5. Miller AL. Therpeutic Considerations of L-Glutamine: A Review of the Literature Altren Med Rev 1999; 4: 239-48.

6. Tannuri U, Carrazza FR. Iriya K. The effects of glutamine supplemented diet on the intestinal mucosa of the malnourished growing rat; Rev Hosp Clin Fac Med sao Paolo 2000; 55: 87-92.

7. Grimble RF. Immunonutrition. Curr Opin Gastroenterol 2005; 21: 216-22. 